\title{
症例
}

特発性血小板減少性紫斑病を合併した胃癌の 1 手術例

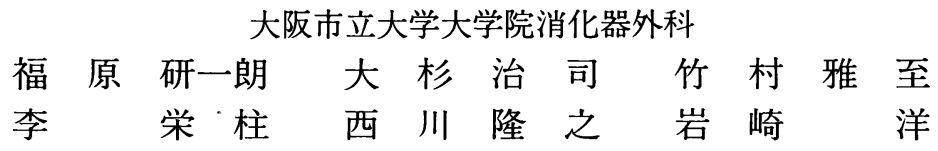

\section{A Case of Total Gastrectomy for Gastric Cancer with Idiopathic Thrombocytopenic Purpura}

Kenichiro FUKUHARA, Harushi OSUGI, Masashi TAKEMURA, Shigeru LEE, Takayuki NISHIKAWA and Hiroshi IWASAKI

Department of Gastroenterological Surgery, Osaka City University Graduate School of Medicine

症例は75歳, 男性。 3 年前より血小板減少を指摘されていたが, 無治療で放置していた。 1 力月間で $5 \mathrm{~kg}$ の体 重減少を認めたため近医を受診し，上部消化管内視鏡検查にて胃癌を指摘され，当科へ紹介となった。入院時血

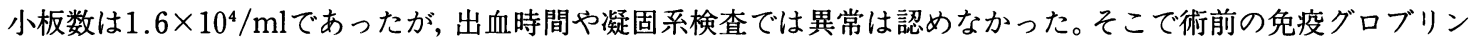
大量投与および術前中の血小板輸血を併用し，胃全摘術・D2リンパ節郭清術・脾摘術・Roux-Y法再建術を施行 した。出血量は $260 \mathrm{~g} て ゙$ 術後合併症もなく, 順調に回復した。特発性血小板減少性紫斑病は原因不明であるが, 悪 性腫瘍との合併頻度は比較的高いとされており, 早期発見による手術侵襲軽減や，より安全な術前後管理が肝要 と思われる。

索引用語：特発性血小板減少性紫斑病（ITP), 胃癌 (gastric cancer), 免疫グロブリン大量療法 (immunoglobuline)

\section{はじめに}

特発性血小板減少性紫斑病 (ITP) は, 比較的稀 な疾患であり，原因は究明されておらず，明確な 治療方法がない難治性疾患である。今回われわれ は, ITPを合併した胃癌症例に対して, 術前免疫グ ロブリン大量療法と血小板輸血を行うことで, 安 全に胃全摘術を施行できた 1 例を経験したので報 告する。

\section{症例}

症 例：75歳, 男性。

家族歴：特記事項なし。

既往歴： 5 年前に右肺炎に対し, 点滴加療を行 い軽快した。
現病歴：入院 2 力月前より 1 カ月に $5 \mathrm{~kg}$ の体 重減少を認めたため近医を受診し，上部消化管内 視鏡検査にて胃病変を指摘されたが，血小板減少 症合併のため当科へ紹介, 手術目的にて入院とな った。

入院時現症：右下肺野にfine crackleをわずか に聴取した。紫斑や皮下出血斑は認めなかった。

入院時検查所見：入院時血小板数は $1.6 \times 10^{4} /$ $\mathrm{ml}$ であったが, 出血時間の延長や凝固系検査で異 常は認めなかった（Table 1)。

胸部レントゲン写真・CT所見：右下肺野に器 質化病変を認め, 器質化肺炎と診断された。

上部消化管内視鏡所見：胃体上部小彎に辺縁不 明瞭なIIc型病変を認め, その口側端は食道胃接合 部より約 $4 \mathrm{~cm}$ に達していた (Fig. 1$)$ 。生検による 
特発性血小板減少性紫斑病を合併した胃癌の 1 手術例

Table 1 Laboratory data on admission

\begin{tabular}{lrllrl}
\hline WBC & $5800 \times 10^{2} / \mu 1$ & $\mathrm{CRP}$ & $0.01 \mathrm{mg} / \mathrm{dl}$ \\
$\mathrm{RBC}$ & $408 \times 10^{4} / \mu \mathrm{l}$ & $\mathrm{TP}$ & $6.6 \mathrm{~g} / \mathrm{dl}$ \\
$\mathrm{Hb}$ & $13.1 \mathrm{~g} / \mathrm{dl}$ & $\mathrm{Alb}$ & $4.3 \mathrm{Gg} / \mathrm{dl}$ \\
$\mathrm{Ht}$ & $39.4 \%$ & $\mathrm{BUN}$ & $19 \mathrm{mg} / \mathrm{dl}$ \\
$\mathrm{PLT}$ & $1.6 \times 10^{4} / \mu \mathrm{l}$ & $\mathrm{Cre}$ & $0.77 \mathrm{mg} / \mathrm{dl}$ \\
$\mathrm{PT}$ & $99 \%$ & $\mathrm{Na}$ & $142 \mathrm{mEq} / 1$ \\
TH-T & $78 \%$ & $\mathrm{~K}$ & $4.4 \mathrm{mEq} / 1$ \\
APTT & $35.1 \mathrm{sec}$ & $\mathrm{Cl}$ & $105 \mathrm{mEq} / 1$ \\
FBG & $247 \mathrm{mg} / \mathrm{dl}$ & $\mathrm{T}-\mathrm{Bil}$ & $0.6 \mathrm{mg} / \mathrm{dl}$ \\
AT3 & $81 \%$ & $\mathrm{AST}$ & $17 \mathrm{IU} / 1$ \\
FDP & $<1.0$ & $\mu \mathrm{g} / \mathrm{ml}$ & $\mathrm{ALT}$ & $16 \mathrm{IU} / 1$ \\
出血時間 & 2 & $\mathrm{~min}$ & $\mathrm{CEA}$ & $3.7 \mathrm{ng} / \mathrm{ml}$ \\
$\mathrm{HBs}-\mathrm{Ag}$ & $(-)$ & $\mathrm{C} . \mathrm{I}$. & $\mathrm{CA} 19-9$ & $1 \mathrm{U} / \mathrm{ml}$ \\
HCV-Ab & 2.6 & C.I. & IAP & $192 \mathrm{~g} / \mathrm{ml}$ \\
\hline
\end{tabular}

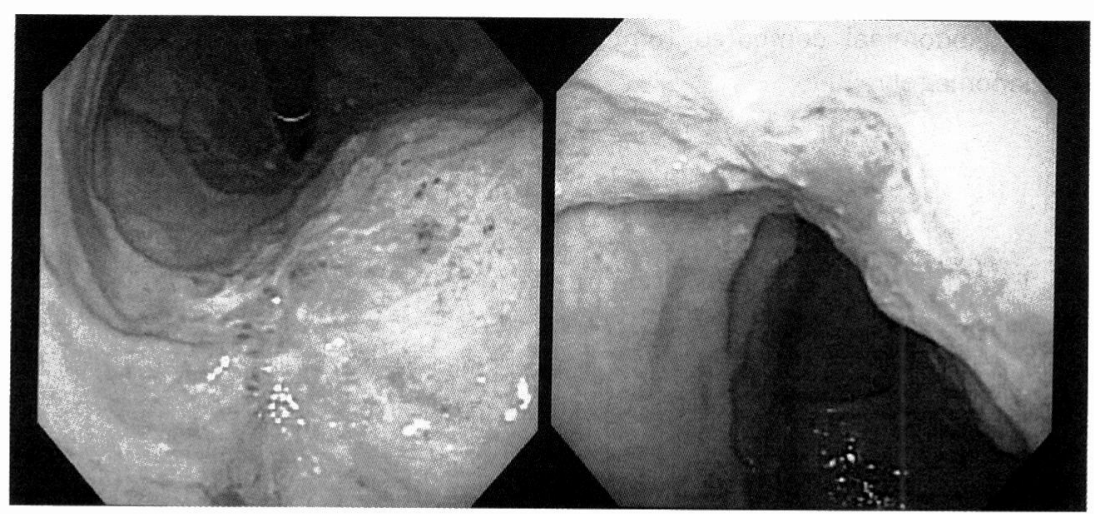

Fig. 1 Endoscopic examination revealed type 2 gastric carcinoma located in the upper body of the stomach and was diagnosed moderately differenciated adenocarcinoma with biopsy specimen.

病理組織検査で中分化型腺癌と診断された。なお， 胃粘膜へのH. pylori感染は陰性であった。

腹部CT所見：主病巣は胃体上部小彎にわずか な壁肥厚として捉えられたが，胃周囲には有意な リンパ節腫脹や肝転移は認めなかった。脾腫は認 めなかった (Fig. 2)。

骨髄穿刺・細胞診所見：巨核球の増多を認めた のみで, 覀性腫瘍などは認めなかった。

術前経過：術前の免疫グロブリン大量投与 (400 $\mathrm{m} / \mathrm{kg} /$ day $\times 5$ 日) および術前日の血小板輸血 (20 単位）を併用し，手術に臨んだ。グロブリン投与 開始 3 日目から 5 日目に 1 日 1 回 37.5 度の微熱を 認めたが, 自覚症状はなかった。なお, 術当日の 血小板数は $14.4 \times 10^{4} / \mathrm{ml}$ であった（Fig. 3)。

手術所見：術中に血小板輸血（20単位）を併用 しつつ, 胃全摘術・D2リンパ節郭清術・脾摘術・
Roux-Y法再建術を施行した。出血量は260gで出 血傾向は認めなかった。主病巣は胃体上部小彎に 位置し, 触知できたが漿膜に露出していなかった。 有意なリンパ節腫脹や肝転移・腹膜播種・腹水貯 留も認めなかった。肉眼所見はM, Less， 3 型, T2, N0, H0, P0, CY0, sStageII, $\mathrm{PM}(-)$, $\operatorname{DM}(-)$, CurAであった。

摘出標本・病理組織検査所見：胃体上中部小彎 に位置する境界不明瞭なII c病変であった。取扱い 規約上, UM, 0-IIc, 高分化型腺癌, sm1, ly0, v0，n0，PM (-)，DM(-), pstage I aであった。

術後経過：血小板数は, 術翌日には $19.6 \times 10^{4} /$ $\mathrm{ml}$ で, その後増加し, 4 日目には $23.5 \times 10^{4} / \mathrm{ml}$ の ピークとなり，14日目には $15.7 \times 10^{4} / \mathrm{ml}$ と安定し た (Fig. 3)。術後は出血もなく凝固能に異常所見 は認めなかった。術 4 日目より水分開始, 術 7 日 


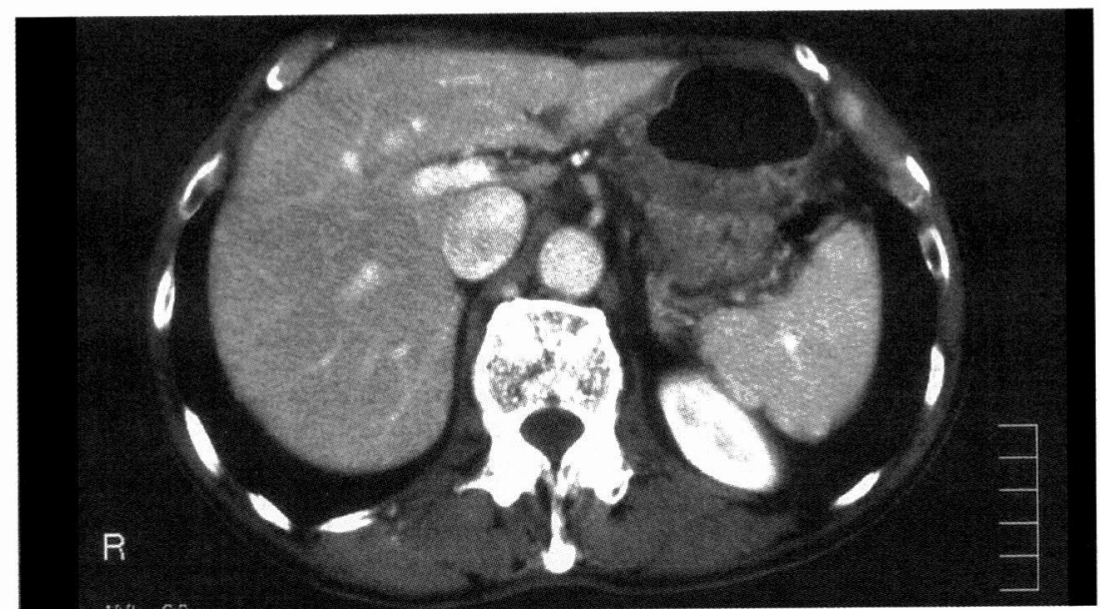

Fig. 2 Abdominal computed tomography showed no gastric lesion and no splenomegaly.

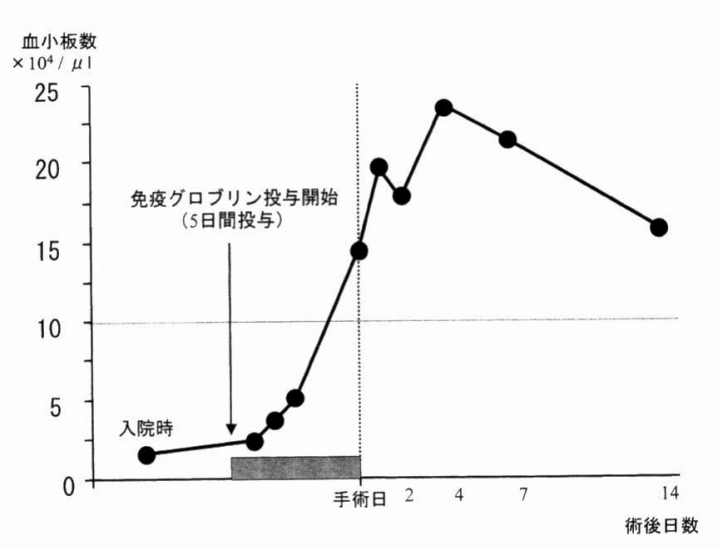

Fig. 3 The counts of the platelet was $1.6 \times 10^{4} / \mathrm{ml}$ on admission, $14.4 \times 10^{4} / \mathrm{ml}$ on the operative day and $23.5 \times 10^{4} / \mathrm{ml}$ on the $4^{\text {th }}$ operative days.

目には食事開始し，特に合併症なく術17日目に退 院となった。

\section{考察}

ITPは抗血小板抗体産生による網内系での血小 板破壊がえ進し，血小板寿命の短縮を原因とする 疾患であり，血小板数減少を主な病態としている が, その発生原因には不明点が多い。ITP自体が難 治性疾患で, 出血性要素を合併しており, 特にリ ンパ節郭清を伴う悪性腫瘍切除術に際しては, 血 小板増加を主とする術前治療および管理が必要と なる。さらに術中出血だけでなく, 術後腹腔内再
出血や創感染, 創治癒遷延のリスクも発生するた め, 術後管理も非合併例に比べ, 一層重要となる。 ITPに対する治療法には, 治療ガイドラインに よると, ステロイド剤の投与, 免疫抑制剂の投与, 脾摘, 血小板輸血, 新鮮血輸血, 交換輸血などが 一般的となっているが，治療の第 1 選択とされて いるステロイド剂の投与による寛解率は10～20\% 程度にとどまると報告されている11。また, ステロ イド剂投与によって, 術後の易感染性や消化性潰 瘍の発症, 高血糖などのさまざまな副作用を引き 起こしうることに加え, 血小板が増加するまでに は 1 〜 週間の期間を要すると報告されてい る ${ }^{1}$ 。手術を前提とした患者には, ステロイド剤投 与治療のみでは術前に十分な血小板の増加を期待 できる確率は低いと言わざるを得ないのが現状で ある。

1981年Imbachら ${ }^{2)}$ が小児のITPに対し完全分子 型免疫グロブリンを大量投与し, 血小板数の上昇 と臨床症状の改善を報告したことから，ITPに対 する免疫グロブリン大量療法が注目され， Schmidt ${ }^{3)}$ が成人においても成功をおさめ，その 有用性が注目されるようになった。この免疫グロ ブリン大量療法による血小板増加の機序として は, (1)intact IgGが大領食細胞のFcレセプターと 結合して飽和させることで，抗体または免疫複合 体の付着した血小板の貪食を抑制し，血小板数を 増加させる，(2)血中の抗血小板抗体の血小板への 
結合を阻止する, (3)抗血小板抗体産生機構の抑制, などが考えられているが223), その詳細な機序は不 明なままである。しかしながら, 増子らの報告に よれば，本邦における免疫グロブリン大量療法の 奏功率は $87.5 \%$ と極めて高く, 効果発現が短期間 で重篤な合併症も報告されていないため, ITP合 併症例の術前の血小板管理に対して, 非常に広く 使用されている4)。免疫グロブリン大量療法は, 一 般的には $400 \mathrm{mg} / \mathrm{kg} / \mathrm{day} \times 5$ 日投与とし，早けれ ば投与開始後数日で血小板数の上昇を認め, 5 〜 7 日目頃にピークをむかえるため, 術予定 5 日 前より投与開始するのが通常である。なお, 比較 的稀な合併症としては, 本例で認めたように微熱 が約 $0.5 \%$ に起こるとされている。全症例に免疫グ ロブリン大量療法を施行するかどうかについては 議論の分かれるところであるが, 出血時間や凝固 系に異常なく, 出血傾向も認めなくても, 手術を 契機に出血傾向が出現したという報告5ももり, われわれは安全な手術施行のためには術前免疫グ ロブリン大量療法は有用と考えた。

ITPはその病因が抗血小板抗体を中心とする体 液性免疫異常のみならず, $\mathrm{T} \cdot \mathrm{B}$ 細胞を中心とする 細胞性免疫の異常が関与していると考えられてお $\eta^{6)}$, 発癌と深い関係があると考えられている。

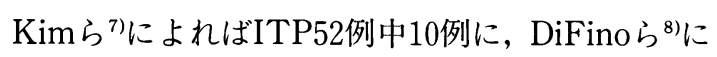
よれば59例中12例に悪性腫瘍の合併が認められ, しかも従来から知られているように造血器やリン パ系の血液悪性疾患との合併が多いとされている 一方 ${ }^{9}$, 少なからず固形癌も認められている。ま た, 脾摘やステロイド, 免疫抑制剂など, ITPに対 する治療そのものが発癌リスクの可能性を有して いる可能性を示唆する報告もある10)。さらに, ITP 患者に有意にIAP (immunosuppressive acidic protein）值が高いという報告もあり ${ }^{11}$, ITPと癌 の発生が深い関係を持っている可能性も示唆され ている。ITPやITP合併悪性腫瘍で入院された際 には，他の悪性腫瘍の検索も念頭に置くべきであ ると思われる。

近年ではITPと H. pyloriの関係についての報告 がなされており，1998年Gasbarriniら ${ }^{12)} に よ る$ 慢 性ITPに対するH. pylori除菌療法の有用性が報告 されてから本邦でも導入されている。重戸ら ${ }^{131}$ は
ITP症例61例中53例でH. pylori感染陽性で，广ち 44例に除菌を施行して除菌成功例28例中20例

(71.4\%) でITPが改善したと報告している。本症 例でも入院後上部消化管内視鏡検查を行い, $H$. pylori感染の有無について検索を行ったが，本症 例では陰性であった。待機手術が可能な症例につ いては, 術前にH. pylori感染の有無を検索するこ とも重要と思われる。

\section{まとめ}

ITP合併胃癌に対して, 免疫グロブリン大量療 法と血小板輸血を用いることで術直前に血小板数 増加に奏効し, 通常通りのリンパ節郭清を含む胃 全摘術を安全に施行することができた。さらに脾 摘術も同時に行うことでITP自体の治療にもつな がった。ITP合併症例の術前には十分な術前精査 を行い, 徹底した術前後の患者管理が必要と思わ れた。

\section{参考文献}

1）熊谷 朗, 吉田象二, 富岡玫夫：本邦における特 発性血小板減少性紫斑病の治療に関する統計的 考察. 第 1 報中間報告厚生省特定疾患特発性血小 板減少性紫斑病調查研究班, 昭和 49 年度研究業 績報告書, 1975, p430-445

2) Imbach $P$, Barandun $S$, d'Apuzzo V, et al : High -dose intravenous gammaglobulin for idiopathic thrombocytopenic purpura in childhood. Lancet $1: 1228-1231,1981$

3) Schmidt RE, Budde U, Schaefer G, et al : High -dose intravenous gammaglobulin for idiopathic thrombocytopenic purpura. Lancet $2: 475$ 476, 1981

4）増子 寛, 坂本 隆, 日野浩司他: 特発性血小板 減少性紫斑病（ITP）を合併した胃癌の1例. 臨 外50：1079-1084, 1995

5）大浦裕之, 佐川元保, 吉田浩幸他：特発性血小板 減少性紫斑病（ITP）を合併した肺癌の手術例。 胸部外科 $49: 484-486,1996$

6）水野嘉夫, 馬場良子, 竹内伸也：胃・直腸重複癌 を合併し, 免疫グロブリン大量療法により摘出可 能であった特発性血小板減少性紫斑病の1例. 免 疫と疾患 $8 ： 931-935,1984$ 
7) Kim HD, Boggs DR : A syndrome resembling idiopathic thrombocytopenic purpura in 10 patients with diverse forms of cancer. Am J Med 67 :371-377, 1979

8) DiFino SM, Lachant NA, Kirshner JJ, et al : Adult idiopathic thrombocytopenic purpura: clinical findings and response to therapy. Am J Med 69 : 430-442, 1980

9) Ebbe $S$, Wittle B, Dameshek W : Autoimmune thrombocytopenic purpura ("ITP" type) with chronic lymphocytic leukemia. Blood 19 :2337, 1962

10) Imbach $P$, Barandun $S$, Baumgartner $C$, et al : High dose intravenous gammaglobulin therapy of refractory, in particular idiopathic thrombocytopenia in childhood. Helv Paediat $46: 81$ $-86,1981$

11) Stefan G, Wolf $K:$ Immunosuppressive acidic protein in malignant disease. Cancer $67: 610$ 612, 1991

12) Gasbarrini A, Franceschi $F$, Tartaglione $R$, et al: Regression of autoimmune thrombocytopenia after eradication of Helicobacter pylori. Lancet $352: 878,1998$

13）重戸伸幸, 清水慎一：特発性血小板減少性紫斑病 に対するHelicobacter pylori除菌療法. 日消病会 誌101：598-601，2004 